\title{
A Comprehensive Review on Various Aspects of Genetic Disorders
}

\author{
Asad Khan \\ MPhil Zoology, Hazara University, Pakistan \\ E-mail: asad_char99@yahoo.com \\ Ihsan Khan \\ MPhil Biotechnology, Quaid-i-Azam University, Pakistan \\ E-mail: Danish_ihsan88@yahoo.com \\ Suleman \\ MPhil Zoology, Hazara University, Pakistan \\ E-mail: Zaheer0332@gmial.com
}

Khan Zahid

MPhil Zoology, Hazara University, Pakistan

E-mail: Khanzahid370@yahoo.com

Ghulam Nabi (Corresponding Author)

MPhil Endocrinology, Department: Animal sciences, Lab: Reproductive neuro-endocrinology

Quaid-i-Azam University, Islamabad, Pakistan

Tel: 92-345-811-2741Ｅ-mail: ghulamnabiqau@gmail

Received: March 30, 2015 Accepted: April 14, 2015

doi:10.5296/jbls.v6i2.7342 URL: http://dx.doi.org/10.5296/jbls.v6i2.7342 


\section{Abstract}

Congenital defects are main causes of new born and child anomalies and morality, which cause single or multiple defects in one or many organs of the child. Worldwide each year about $3 \%$ of 134 million annual births are affected by major structural and functional defects. Birth defects may have a genetic infection or environmental sources but about $50 \%$ of all congenital disorders still have no exact cause. This review article focuses on the causes of genetic disorders, types of genetic disorders, development of genetic disorders, epidemiology and prevention of genetic disorders.

Keywords: Anomalies, Congenital, Epidemiology, Mortality.

\section{Introduction}

A genetic disorder is restriction of normal health which results from a change in an individual's genome. Genetic disorder may be due to chromosomal abnormalities, environment factors or both but some time unknown (Bushman, 2000). Environmental factors such as air pollution and proximity to harmful waste sites increase the ricks for structural birth defects (Ritz et al., 2002). Drug use, infections from mother, maternal exposure to chemical; these physical environmental factors are also concerned. Treatment and therapy of genetic disorders are costly and complete recovery is commonly impossible. Various genetic disorders are lethal. Lethal disorders exist in populations are recessive, as lethal dominant disorders are eliminated through natural selection by deaths of carriers before they pass the disease to next generation. The frequencies of different genetic disorders depend upon various factors such as genetic background of the population and the type of environment to which the population is exposed (Risch et al., 2002; Charles et al., 2003; GDF, 2010).

\section{Single Gene Disorders}

Disorders caused by a mutation in single gene followed the pattern of inheritance as describe $\mathrm{d}$ by Mendel. The Online Mendelian inheritance in Man (OMIM) contains a complete record of these genes and genetic disorders (OMIM, 2013). Worldwide frequencies of all monogenic disorders at birth are about 10/1000 (WHO, 2013). The "monogenic" diseases provide unique opportunities to dissect components as they each have a single etiology, comparatively uniform treatments, and the role of the disease-causing gene is known to some extent (Antonarakis and Beckmann, 2006) Single gene disorders are passed on to successive generations in several ways. In autosomal dominant disorders one copy of mutated gene is involved .In autosomal recessive disorders two copies of the mutated gene are essential for a person to be affected. Dominant mutations cause X-linked dominant disorders. Male and female are both affected by these disorders. In recessive mutations, mutant genes are located on X-chromosome cause X-linked recessive disorders. These disorders affect both males and females with males more commonly affected than females (Muscatelli et al., 1994). Y-linked disorders results from mutations in genes on Y-chromosome. In Y- linked disorders only male are affected. Embryos having abnormal chromosomes stop developing before birth. Abnormal chromosomes account for at least $50 \%$ of natural abortions, however, only $0.65 \%$ 
of newborns have abnormal karyotype. The pattern of inheritance of mitochondrial genes differs from that of genes in the nucleus, only mother can pass mitochondrial genes to next generations as sperm generally never contribute mitochondria when they fertilize an oocyte (Lewis, 2005).

\section{Complex genetic disorders}

In human being most genetic disorders are complex. A few examples include asthma, Alzheimer's disease, osteoporosis, Parkinson's disease, scleroderma, and others (Hunter, 2005; Dempfle et al., 2008; Johnson et al., 2009). In complex genetic disorders, one to one relationship between the trait phenotype and genotype does not exist (dravasi, 1998). These disorders are commonly due to both environmental and genetic factor (Hunter et al., 2005). Epigenetic mechanisms have been linked to a large range of diseases such as Prader-Willi syndrome, Angelman's syndrome, Rett syndrome, Rubinstein-Taybi syndrome and Cofffin-Lowry syndrome (Egger et al., 2004; Portela et al., 2010).

\section{Gene and Development}

A human body consists of about 50 to 100 trillion cells. A single cell, that is the fertilized egg, gives rise to such a huge number of different cell types such as blood cells, epidermal cells, fat cells, lens cells, lymphocytes, muscles cells, neurons and so on, through the process of differentiation. During differentiation specific combinations of genes are switched on (expressed) or switched off (repressed) to dictate cell morphology and function. This process of gene expression is regulated by a complex interplay of signals from both within and outside of cells (Liang et al., 1992; Hwang et al., 2009).

\section{Limb Development: An Example of How Genes Play Role in Development?}

The vertebrate limb is a complex structure composed of many different tissue types. Many genes are required to start limb development but successive patternings of the limb bud are now known (Beermann et al., 2004). These genes are expressed in the same patterns in both the developing forelimb and hind limb, and are believed to play equal roles in generating homologous limb elements; for example, fingers in the hand and toes in the foot. The limb development is model system for the study of developmental dynamics and genetics because it is relatively easy to control and can be subjected to mutations of large effects that otherwise would not be fatal to the body, additionally its mesenchymal cells, when grown in culture, can undergo formation pattern and differentiation with a time course and on a spatial level similar to that of embryo (Yakushiji et al., 2009).

Bud outgrowth of both forelimb and hind limb is started when cells within the prospective limb-forming region of lateral plate mesoderm (LPM) starts responding to signals from more medial tissues. LPM is a type of mesoderm that originates at the border of the embryo. The LPM consists of two line of tissue that runs along the length of the main body axis, lateral to the somites (Capdevila et al., 2001). In the start, the limb buds are morphologically identical collections of cells, and later on they develop into morphologically different limb elements. In the somites myotomal cells originate medial to the limb bud, migrate into the limbs and give rise to limb musculature (Logan, 2003). The limb has three main axes: (1) The 
anteroposterior axis that runs from the thumb or big toe towards the little finger or toe, correspondingly; (2) the proximodistal axis that runs from the shoulder or hip towards the tips of the digits; and (3) the dorsoventral axis passes from the back to the front of the hand or foot. There are key signaling centers for developing limb bud that control patterning of each limb axis. A collection of cells called zone of polarizing activity (ZPA) at the posterior region of limb bud control pattering of the anteroposterior axis by the expression of secreted protein Shh (Tickle, 2005). A specific structure of ectodermal cells called apical ectodermal ridge (AER) that runs along the length of the distal tip of the limb bud control patterning of proximo-distal axis by expressing proteins that belong to the FGF family of secreted proteins (Martin, 1998). Meis genes that are induced by retanoic acid (RA) in the proximal limb bud emerge to control the development of proximal structures, thus indicating that proximo-distal axis patterning is controlled by a combination of opposing RA and FGF signals (Capdevila et $a l ., 2001)$. Wnt7a signaling from the dorsal ectoderm into the underlying mesoderm control patterning of the dorsoventral axis (Chen et al., 1999).

\section{Mutations in Human Hox Genes and Associated Phenotypes}

Vertebrate Hox genes encode a family of transcription factors which play a key role of body patterning during embryonic development. Like humans, majority of the vertebrate have 39 Hox genes which are organized into four set of Hox genes namely Hoxa, Hoxb, Hoxc and Hoxd. similarity in sequencing of these genes show that they are evolved from single ancestral cluster of gene that's why single Hox genes in cluster are directly homologous to other three clusters (Charles., et al 1998). Hox genes play main role in the development of central nervous system, axial skeleton, gastrointestinal, urogenital tracts, external genitalia and limbs (Goodman, 2002). Little knowledge is available about expression and regulation of Hoxb and Hoxc genes during limb development however, the expressions of Hox genes are limited to development of fore or hind limbs (Charite et al., 1994; Peterson et al., 1994). Regulation of polyalanine stretch can cause heterozygous synpolydactyly (SPD); syndactyly of fingers 3-4 and toes 4-5 with polydactyly in the cutaneous web between digits), homozygous SPD (Malik et al., 2008), short hands and feet, complete soft tissue syndactyly of all four limbs, preaxial, mesoaxial, and postaxial polydactyly of hands loss of tubular shape of carpal, metacarpal, and phalangeal bones, tarsal-metatarsal fusions, loss of normal phalangeal pattern and hypospadias (Muragaki et al. 1996; Akarsu et al., 1996; Goodman et al., 1997). Mutation in Hoxd cluster can leads to monodactyly, biphalangel digits absence of carpal ossification in four limb and cryptorchidism (Camp et al., 1998).

\section{Tbx5 Mutations and Genetic Disorders}

Tbx trancptional families have important role in development and disease. Experiment which explain function of Tbx gens are clinically important because mutation in Tbx genes are associated with Holt-Oram Syndrome (HOS) (OMIM 142900), a dominant disorder that is characterized by upper (fore) limb anomalies and heart defects (Basson et al., 1997; Li et al., 1997). Mutations in Tbx 3 and Tbx 4 result ulnar-mammary syndrome which are associated with upper limb abnormalities (Bamshad et al., 1997). Haploinsufficiency of Tbxs cause a number of limb defects, the mildest phenotype being triphalangeal thumb but which most 
frequently results in the collapse of limb elements to form. A regular characteristic of HOS is that abnormalities affect the anterior structures of the limb, such as the thumb or radius (Logan, 2003).

\section{Genetic Epidemiology}

Genetics epidemiology is quickly expanding research field concerned with considerate the heritable aspect of disease risk, individual propensity to disease and eventually with contributing to a complete molecular understanding of pathogenesis (Smith et al., 2005). It is a discipline that focuses on the familial and in particular genetic determinants of disease and the joint effects of genes and non-genetic determinants (Burton et al., 2005). A major issue for genetic epidemiology is being able to identify both, environmental and genetic factors that alter risk in individuals who have, or are strongly suspected of having inherited disease-predisposing mutations. Obtaining this information requires large numbers of known carriers and their relatives, but suitable statistical inferences about modifiers of risk are difficult if ascertainment of the families was not systematic and well designed. Population-based case-control family studies are likely to give clearer answers than analysis of members of mutation-carrying families ascertained through opportunistic sampling from genetics clinics (Hopper et al., 2005).

\section{Prevalence of Genetic Disorders}

Structural or functional including metabolic disorders are known to congenital abnormalities which are present at the time of birth (WHO, 2013; Zhang et al., 2012). According to literature congenital defects are main causes of new born and child anomalies and morality, which cause single or multiple defects in one or many organs of the childs. Globally each year about $3 \%$ of 134 million annual births are affected by major structural and functional defects (Czeizel, 2004). Birth defects may have a genetic infection or environmental sources but about $50 \%$ of all congenital disorders still have no exact cause (WHO, 2013). Risk factors which contribute singly or interactively to birth defects include genetics, hazardous chemicals, physical and biological issues and maternal elements (Wilson, 1997). Additionally different risk factors and direct causes of birth defects seen in various parts of the world, prevalence rate also depends on the age of children, the types of malformations, the method of data collection and statistical analysis used in different studies (Zhang et al., 2012).

\section{Consanguinity a Risk Factor for Genetic Disorders}

The term "consanguinity" is used to illustrate unions between individuals who are known to share genes inherited from one or more frequent ancestors. Additionally the most common consignees' marriage is first cousin marriages which have $12.5 \%$ common gene pool (Bittles, 2001). The level of homozygosity in second cousins marriage is different from those observed in general population (Miguel et al., 2005). Consanguinity increases the prevalence of rare genetic congenital anomalies and nearly doubles the risk for neonatal and childhood death, intellectual disability and serious birth anomalies in first cousin unions (WHO, 2013). The frequency of congenital anomalies is higher in consanguineous marriages compared to non-consanguineous marriages (Tayebi et al., 2010). Fertility index and death, especially in 
the first year of life, were extensively higher in consanguineous marriages (Kerkeni et al., 2007). In general, consanguinity is fractional by geographic, demographic, religious, cultural, and socio-economic factors. Generally consanguinity is associated with congenital disorders and may other diseases, such as kidney, blood disease barest cancer deafness and many complex disorders (Bener et al., 2007; Gilani et al., 2003)

\section{Maternal Risk Factors for Genetic Disorder}

Food anxiety has not been evaluated with respect to birth defect risks. Iodine deficiency, folate insufficiency, overweight, or conditions like diabetes mellitus are linked to some congenital anomalies. For example, folate insufficiency increases the risk of having a baby with neural tube defects. Maternal exposure to certain environmental factors such as pesticides, medicinal and recreational drugs, alcohol, smoking tobacco, certain chemicals, high doses of vitamin A during early pregnancy, and high doses of radiation increase the risk of having a baby with congenital anomalies. Working or living near or in waste sites, smelters, or mines may also be a risk factor (WHO, 2013).

\section{Diagnosis and Prevention of Genetic Disorders}

Genetic counseling involves an attempt to assist a person's understanding of his or her risk for a genetic disorder and understanding of options for dealing with the risk of occurrence without causing undue concern (Clarke et al., 1996). For fetus or embryo information the use of all designed technique during parental diagnosis. Before and after prenatal diagnosis some genetic counseling must be offered (Wieacker et al., 2010). Newborn screening identifies conditions that can affect a child's long-term health or survival. Early detection, diagnosis, and intervention can prevent death or disability and enable children to reach their full potential (CDCP, 2013).

\section{Conclusion}

The incidences of genetic disorders are increasing year from year due to high rate of consanguinity and chronic exposure to various environmental pollutants. If such conditions persist, the percentage of genetic disorders will abruptly increase. In such communities awareness should be created against the negative effects of consanguinity and about the hazardous effects of various pollutants on incoming progeny. Families at risk are advised newborn screening as early detection, diagnosis, and intervention can prevent death or disability and enable children to reach their full potential

\section{References}

Andrew E. Czeizel (2004). The primary prevention of birth defects: Multivitamins or folic acid Int. J. Med. Sci, 1(1), 50-61. http://dx.doi.org/10.7150/ijms.1.50

Bamshad M, Lin RC, Law DJ, Watkins WC, Krakowiak PA, Moore ME, Franceschini P, Lala R, Holmes LB, Gebuhr TC, Bruneau BG, Schinzel A, Seidman JG,Seidman CE, Jorde LB (1997). Mutations in human TBX3 alter limb, apocrine and genital development in ulnar-mammary syndrome. Nat Genet, 16(3), 311. 
Basson CT, Bachinsky DR, Lin RC, Levi T, Elkins JA, Soults J, Grayzel D, Kroumpouzou E, Traill TA, Janine Leblanc-Straceski J, Renault B, Kucherlapati R, Seidman JG, Seidman CE (1997). Mutations in human cause limb and cardiac malformation in Holt-Oram syndrome. Nature Genetics, 15(1), 30-35. http://dx.doi.org/10.1038/ng0197-30

Bener A, Hussain R, Teebi AS (2007). Consanguineous marriages and their effects on common adult diseases: studies from an endogamous population. Med Princ Pract, 16, 262-7. http://dx.doi.org/10.1159/000102147

Bittles AH (2001). Consanguinity and its relevance to clinical genetics. Clin Genet, 60, 89-98. http://dx.doi.org/10.1034/j.1399-0004.2001.600201.x

Burton PR, Tobin MD, Hopper JL (2005). Key concepts in genetic epidemiology. The Lancet, 366, 9489, 941-951. http://dx.doi.org/10.1016/S0140-6736(05)67322-9

Bushman B, (2000). Tomlinsons pathology lecture. PMID: 6519-344.

Camp BW, Broman SH, Nichols PL, Leff M (1998). Maternal and neonatal risk factors for mental retardation: defining the at-risk" child. Early Human Development, 50(2), 159-173. http://dx.doi.org/10.1016/S0378-3732(97)00034-9

Capdevila J, Belmonte JCI (2001). Patterning mechanisms controlling vertebrate limb development. Annual Review of Cell and Developmental Biology, 17(1), 87-132. http://dx.doi.org/10.1146/annurev.cellbio.17.1.87

Chapman DA, Scott KG, Mason CA (2002). Early risk factors for mental retardation: Role of maternal age and maternal education. Journal Information, 107(1), 46-59. http://dx.doi.org/10.1352/0895-8017(2002)107<0046:erffmr>2.0.co;2

Chen H, Johnson RL (1999). Dorsoventral patterning of the vertebrate limb: a process governed by multiple events. Cell and Tissue Research, 296(1), 67-73. http://dx.doi.org/10.1007/s004410051267

Clarke A, Parsons E, Williams A (1996). Outcomes and process in genetic counselling. Clinical Genetics, 50(6), 462-469. http://dx.doi.org/10.1111/j.1399-0004.1996.tb02713.x

Dempfle A, Scherag A, Hein R, Beckmann L, Chang-Claude J, Schäfer H (2008). Gene-environment interactions for complex traits: definitions, methodological requirements and challenges. European Journal of Human Genetics, 16(10), 1164-1172. http://dx.doi.org/10.1038/ejhg.2008.106

Egger G, Liang G, Aparicio A, Jones PA (2004). Epigenetics in human disease and prospects for epigenetic therapy. Nature, 429, 6990, 457-463. http://dx.doi.org/10.1038/nature02625

Gilani GM, Kamal S (2004). Risk factors for breast cancer in Pakistani women aged less than 45 years. Ann Hum Biol, 31, 398-407. http://dx.doi.org/10.1080/0301446042000226763

Goodman F, Giovannucci-Uzielli ML, Hall C, Reardon W, Winter R, Scambler P (1998). Deletions in HOXD13 segregate with an identical, novel foot malformation in two unrelated families. American Journal of Human Genetics, 63(4), 992-1000. 
http://dx.doi.org/10.1086/302070

Hopper JL, Bishop DT, Easton DF (2005). Population-based family studies in genetic epidemiology. The Lancet, 366, 9494, 1397-1406. http://dx.doi.org/10.1016/S0140-6736(05)67570-8

Hunter DJ (2005). Gene-environment interactions in human diseases. Nature Reviews Genetics, 6(4), 287-298. http://dx.doi.org/10.1038/nrg1578

Hwang YS, Chung BG, Ortmann D, Hattori N, Moeller HC, Khademhosseini A (2009). Microwell-mediated control of embryoid body size regulates embryonic stem cell fate via differential expression of WNT5a and WNT11. Proceedings of the National Academy of Sciences, 106(40), 16978-16983. http://dx.doi.org/10.1073/pnas.0905550106

Lewis R (2005). Human Genetics. Concepts and Applications. 9th Edition.

Li QY, Newbury-Ecob RA, Terrett JA, Wilson DI, Curtis AR, Yi CH, Gebuhr T, Bullen PJ, Robson SC, Strachan T, Bonnet D, Lyonnet S, Young ID, Raeburn JA, Buckler AJ, Law DJ, Brook JD (1997). Holt-Oram syndrome is caused by mutations in TBX5, a member of the Brachyury (T) gene family. Nature Genetics, 15(1), 21-29. http://dx.doi.org/10.1038/ng0197-21

Liang P, Pardee AB (1992). Differential display of eukaryotic messenger RNA by means of the polymerase chain reaction. Science, 257, 5072, 967-971. http://dx.doi.org/10.1126/science. 1354393

Logan M (2003). Finger or toe: the molecular basis of limb identity. Development, 130(26), 6401-6410. http://dx.doi.org/10.1242/dev.00956

Malik S, Grzeschik KH (2008). Synpolydactyly: clinical and molecular advances. Clinical Genetics, 73(2), 113-120. http://dx.doi.org/10.1111/j.1399-0004.2007.00935.x

Martin GR (1998). The roles of FGFs in the early development of vertebrate limbs. Genes \& Development, 12(11), 1571-1586. http://dx.doi.org/10.1101/gad.12.11.1571

Miguel A, Alfonso-sa'nchez, Jose AP. (2005). Effects of Consanguinity on Pre-reproductive Mortality: DoesDemographic Transition Matter? AMERICAN JOURNAL OF HUMAN BIOLOGY, 17, 773-786. http://dx.doi.org/10.1002/ajhb.20444

Muragaki Y, Mundlos S, Upton J, Olsen BR (1996). Altered growth and branching patterns in synpolydactyly caused by mutations in HOXD13. Science, 272, 5261, 548-551. http://dx.doi.org/10.1126/science.272.5261.548

Portela A, Esteller M (2010). Epigenetic modifications and human disease. Nature Biotechnology, 28(10), 1057-1068.http://dx.doi.org/10.1038/nbt.1685

Risch N, Burchard E, Ziv E, Tang H (2002). Categorization of humans in biomedical research: genes, race and disease. Genome Biol, 3(7), 1-12. http://dx.doi.org/10.1186/gb-2002-3-7-comment2007 


\section{Macrothink}

Ritz B, Fruen S, Chapa G, Shaw GM, Harris JA (2002). Ambient air pollution and risk of birth defects in southern California. Am. J. epidermal, 155, 17-25.

Smith GD, Ebrahim S, Lewis S, Hansell AL, Palmer LJ, Burton PR (2005). Genetic epidemiology and public health: hope, hype, and future prospects. The Lancet, 366, 9495, 1484-1498. http://dx.doi.org/10.1016/S0140-6736(05)67601-5

Tayebi N, Yazdani K, Naghshi N (2010). The prevalence of congenital malformations and its correlation with consanguineous marriages. Oman Medical Journal, 25(1), 37-40. http://dx.doi.org/10.5001/omj.2010.9

Tickle C (2005). Making digit patterns in the vertebrate limb. Nature Reviews Molecular Cell Biology, 7(1), 45-53. http://dx.doi.org/10.1038/nrm1830

WHO (2013). http://www.who.int/genomics/public/geneticdiseases/en/index.html

Wieacker P, Steinhard J (2010). The prenatal diagnosis of genetic diseases. Deutsches Ärzteblatt International, 107(48), 857.

Yakushiji N, Yokoyama H, Tamura K (2009). Repatterning in amphibian limb regeneration: A model for study of genetic and epigenetic control of organ regeneration. In Seminars in Cell \& Developmental Biology, 20(5), 565-574. http://dx.doi.org/10.1016/j.semcdb.2008.12.007

Zhang X, Li S, Wu S, Hao X, Guo S, Suzuki K, Yokomichi H, Yamagata Z (2012). Prevalence of birth defects and risk-factor analysis from a population-based survey in Inner Mongolia, China. BMC Pediatrics, 12(1), 125.

\section{Copyright Disclaimer}

Copyright for this article is retained by the author(s), with first publication rights granted to the journal.

This is an open-access article distributed under the terms and conditions of the Creative Commons Attribution license (http://creativecommons.org/licenses/by/3.0/). 